\title{
Contrastive Pragmatics and Corpora
}

\author{
Karin Aijmer \\ University of Gothenburg, Sweden \\ karin.aijmer@eng.gu.se
}

\begin{abstract}
Contrastive pragmatics is closely associated with the use of parallel and comparable corpora for studying the similarities and differences between languages. Parallel corpora have now been extended to more than two languages making them more relevant for typological research, and they can be used to investigate whether there are (discourse) universals across languages. Contrastive pragmatic studies also need to take into account aspects of the communication situation and the social and cultural context. As a result, many contrastive studies nowadays are doubly contrastive in that they compare pragmatic phenomena across both genres and languages. Scholars have also begun to combine contrastive analysis (translations) with the diachronic analysis of pragmatic phenomena in historical corpora, and pragmatic phenomena are studied contrastively with the focus being on sociolinguistic aspects. Illustrating these new uses is a case study which compares English absolutely with Swedish absolut.
\end{abstract}

\section{Keywords}

corpus - pragmatics - contrastive - comparable corpus - parallel corpus - pragmatic marker - speech act - absolutely

\section{Introduction}

The aim of this article is to give an update on the state of the art in contrastive pragmatics and corpora. 'Contrastive corpus pragmatics' can be regarded as a new field of research characterised by the joint approaches of pragmatics, corpus linguistics and contrastive analysis for describing the similarities and differences between languages. The interest in pragmatic phenomena from 
a contrastive perspective in different languages is not new in itself. Ferguson (1981), for example, analysed the patterns of response given to greetings in English and Syracuse Arabic, and Coulmas (1981) examined the use of the routinised speech acts thanks and apologies by drawing on material from a number of European languages and Japanese in a study which he described as "theoretically grounded in contrastive pragmatics" (Coulmas, 1981: 69). Contrastive pragmatic studies have also been influenced by 'the empirical turn' in linguistics, particularly the use of large-scale contrastive corpora which can be used to empirically study the similarities and differences between languages.

Contrastive studies of pragmatic phenomena can be situated within different theoretical frameworks such as functional theories of cohesion, speech act analysis and discourse analysis. ${ }^{1}$ They overlap in their concerns with other disciplines dealing with language comparison such as cross-cultural pragmatics (Wierzbicka, 2003), variational pragmatics (Schneider and Barron, 2008; Barron and Schneider, 2009), intercultural pragmatics (Kecskes, 2017) and 'learner corpora and pragmatics' (Vyatkina and Cunningham, 2015).

Contrastive linguistics is concerned with issues which are relevant to translation, the education of translators and language teaching. "The new contrastive analysis' is also relevant to many other research areas such as diachronic grammaticalisation studies and language typology (see also Aijmer, 2011).

The discussion of corpus-based contrastive pragmatics in this article is organised in the following way. Section 2 deals with the corpus methodology and the type of contrastive projects which are based on translations or comparable corpora. Section 3 discusses the challenges which are involved when using contrastive corpora to investigate pragmatic phenomena. Section 4 is a case study where I show how a contrastive corpus-based methodology can be used to study the similarities and differences between English absolutely and Swedish absolut.

Methodology

A pragmatic perspective on language implies that the focus is on the use of lexical elements or grammatical structures in their linguistic, social and cultural context. The analysis of what linguistic elements are doing in the communication situation is by nature qualitative. However, the emergence of new corpora has now made it possible to combine the qualitative analysis of pragmatic

1 See e.g. Davidse and Heyvaert, 2002/2003 - Special issue of Languages in Contrast on Functional Linguistics and Contrastive Description. 
phenomena with quantitative methods. As a result, pragmatics and corpus linguistics are no longer regarded as separate disciplines, but can be described as having a close symbiotic relationship (Romero-Trillo, 2008).

The most obvious aspect of the corpus analysis of pragmatic phenomena is that it begins by searching for a specific form and then moves to an analysis of its function (O'Keeffe, 2018: 588). "Rather than investigating a fundamental human need to express a particular communicative function, and the forms used to do this, the focus is on one of the [pragmatic] markers and the different senses it has or functions that it can perform" (Beeching and Woodfield, 2015: 7). This form-to-function methodology has the advantage that linguistic elements, such as pragmatic markers, can be studied with great precision with regard to their frequency, function and position in the sentence and discourse, both in monolingual and bilingual corpora. On the other hand, we cannot use a corpus-based methodology in a straightforward way to search for speech acts such as requests, apologies or politeness features (See Section 3.2).

The new focus on empirical contrastive pragmatic studies leads to a discussion about which types of corpora are most suitable for the analysis of pragmatic phenomena across languages. Parallel translation corpora and comparable corpora involve different types of methodologies and are suitable for different research questions.

\subsection{Parallel Corpora}

A parallel (translation) corpus is designed in such a way as to enable the investigation of how a lexical element in one language is translated into another language, by matching a sentence in one language with the corresponding sentence in the other language. The particular advantage of parallel corpora is that they allow the researcher to make specific and fine-grained comparisons on the basis of texts which are interlingually comparable. The texts selected for translation can be either fiction or non-fiction, and they are chosen because they are "especially valid" for comparative purposes (Johansson, 2007: 9).

The disadvantage of parallel translation corpora is that the translations may reflect the influence of the source language on the target language ('translationese'; Baker, 1993; Gellerstam, 1996). It is therefore advisable to base the results on translations going in both directions. In a bidirectional corpus such as the English-Swedish Parallel Corpus (ESPC) four types of paired texts can be investigated: (a) English Original $\rightarrow$ Swedish Translation; (b) Swedish Original $\rightarrow$ English Translation; (c) Swedish Translation $\leftarrow$ English Original; (d) English Translation $\leftarrow$ Swedish Original (Aijmer et al., 1996). By going back and forth from the originals to the translations it is possible to distinguish whether any differences are between the languages or are due to the translation/translator. 
Contrastive analysis aims to make comparisons between two or more paired languages. The majority of these comparisons have English as one of the components, as shown by existing parallel corpora intended for contrastive research. A pioneer in this area is the English-Norwegian Parallel Corpus (ENPC) and the Oslo Multilingual Corpus (OMC) with matching texts across English, Norwegian and German (Johansson, 2007). Parallel corpora have proved to be an important resource for pragmatic studies. The English-Swedish Parallel Corpus (ESPC) has been used in text-based, cross-linguistic studies within modality, discourse connectivity and information structure (Aijmer et al., 1996; Altenberg and Aijmer, 2000). By using the English-Czech and Czech-English sections of the Czech National Corpus-Intercorp, Martinková and Janebová (2017) were able to investigate the meaning of the Czech particle prý via its correspondences in English. The Dutch Parallel Corpus (Macken et al., 2011) has a Dutch-English component which provided material for Buysse's (2017) study of the mutual translatability of Dutch dus and English so. The CroCo Corpus was designed to study the linguistic properties of translation, but has also been used to study differences within the area of textual cohesion in English and German discourse ${ }^{2}$ (Hansen-Schirra and Neumann, 2012).

\subsection{Comparable Corpora}

The use of natural language corpora for contrastive speech act research has often been discouraged because of the difficulty of finding corpora for different languages which can be used for language comparison. Comparable corpora should be similar with regard to design features such as size, time span, etc. They are used for a variety of different purposes and are particularly suitable for analysing pragmatic phenomena in spoken or written text genres where it is difficult to find translations.

Pragmatic phenomena such as pragmatic markers, discourse relations, information structure and politeness are now studied contrastively in political speeches or debates, informal conversation, book reviews, personal narratives, etc. I will discuss the use of comparable corpora for genre-based analysis in Section 3.3.

2 The GeCCo (German-English Contrasts in Translation) project (http://www.gecco.uni -saarland.de/GECCo/index.html). 

Pragmatic Phenomena

The following sections provide an overview of the topics involved with contrastive pragmatics and the theoretical and methodological questions they give rise to.

\subsection{Pragmatic Markers in a Contrastive Perspective}

From a language-typological perspective, parallel and comparable corpora are valuable for comparing lexical elements which have similar meanings in different languages. ${ }^{3}$ The cross-linguistic study of cognates has given new life to the question of whether there are universals across languages. Pragmatic markers which are cognates can, for example, be expected to share many functions since their lexical sources are similar. ${ }^{4}$ Fleischman and Yaguello (2003) showed that English like and the French discourse marker genre de developed the same functions from similar lexical sources and suggested that cross-linguistic studies can be used to form generalisations about discourse universals. Recently it has been questioned whether full correspondence between cognates in different languages is possible. Following on from this idea, scholars who are interested in 'discourse markers across languages' now explore the idea that cognates in different languages are near-synonyms which have similar meanings in some contexts, but not in others (Enghels, 2018). Hasselgård (2006) was interested in examining the correspondences between the cognates now in English and Norwegian nå, which have a temporal meaning but are also used for discourse functions in both languages. The study was hypothesis-driven in line with the assumption that corpus-based contrastive research should be "item-specific, predictive and hypothesis-driven" (Gast, 2015: 4). Hasselgård wanted, for example, to test the hypothesis, derived from previous work on na and now, that they have different discourse properties because they have developed in different ways in English and Norwegian. The English-Norwegian Parallel Corpus (ENPC) was used to take into account the translations of now or nå from the source language into the target language, as well as translations where the direction of the process is reversed. Using this method to search for

3 Pragmatic markers have been a fruitful area of contrastive research. Aijmer and Simon-Vandenbergen (2006) contains a collection of empirical contrastive studies of pragmatic markers from different languages. Lauwers et al. (2010) offer contrastive analyses of pragmatic markers and pragmaticalisation with a focus on cognates or 'false friends'.

4 See Aijmer and Simon-Vandenbergen (2006: 2) on the different uses of the term. In this article, the term pragmatic marker is used as the more general term. 'Discourse marker' refers specifically to pragmatic markers which have a discourse function. 
translation equivalents (correspondences), Hasselgård found that now and nå could seldom be each other's translations and that they were not used with the same frequency as discourse markers. This confirmed the original hypothesis that they were 'false friends' and had developed in different directions in the two languages.

A study of pragmatic markers based on parallel translation corpora can also contribute to more theoretical issues involving their semantic description in terms of monosemy or polysemy. This can be illustrated by the many contrastive studies of the discourse marker well. An important feature of the parallel corpus methodology is a detailed analysis of the functions of well, where translations are helpful in the exploration of the discourse marker's rich multifunctionality. ${ }^{5}$ Well does not have a direct correspondence in many languages but has several different correspondences such as interjections, conjunctions (cf. but), modal particles and omissions (cf. Aijmer and Simon-Vandenbergen, 2003).

Aijmer and Simon-Vandenbergen (2003) used a corpus-driven approach to investigate well and its translations into Swedish and Dutch. By including both Swedish and Dutch in the comparison it was possible to see the contributions provided by each language more clearly and describe the meanings of well in a more general way than would have been possible if the comparison had only been bidirectional. Aijmer and Simon-Vandenbergen's study of well was extended by Johansson (2007) to a comparison of well with Norwegian and German correspondences and by Aijmer (2015) to French data, further illustrating the rich variety of meanings that well can have and confirming the description of its multifunctionality based on fewer languages. Contrastive studies of this kind have led to deeper reflection on the multifunctionality of pragmatic markers and how their meanings should be described. It has, for example, been proposed that well does not have a fixed meaning, but a core meaning from which other meanings can be derived (Norén and Linell, 2007; Aijmer, 2015: 225). Another possibility is that multifunctionality can be described in the relevance theoretical framework by assuming that well functions as a signpost to the hearer to go ahead with the interpretation process involved in the derivation of cognitive effects (Blakemore, 2002).

5 See e.g. Dyvik's (1998) project with the purpose of deriving semantic information from a translation corpus. 
The contrastive analysis of the multifunctionality of pragmatic markers can also be combined with a study of the histories of the markers through the different stages of the grammaticalisation process. The close association between contrastive studies of pragmatic markers and grammaticalisation research can be illustrated by Defour et al.'s (2010) study of the semantic-pragmatic development of actually in English and its French cognate actuellement from their shared origin ('in reality'). Synchronically, actually and actuellement are not correspondences in many contexts, reflecting the fact that the French and English words are not synonymous. Actuellement has a temporal meaning ('now'), while in English actually has developed into a pragmatic marker meaning elaboration or contradiction. The meanings of the cognates are compatible with the hypothesis that they have taken divergent grammaticalisation paths, and that the history of actually involves intersubjectification while actuellement has not developed beyond the temporal sense. The usefulness of this 'panchronic' approach has also been shown by Hansen and Strudsholm (2008) who used a contrastive analysis combining synchrony and diachrony to compare the different meanings of French déjà and Italian gia (cf. English 'already'). Synchronically, fifteen different uses of déjà and gìa were distinguished, but only eight of these were shared by the two markers, which is in line with the view that grammaticalisation can take divergent views depending on the language.

The synchronic and diachronic analyses which showed the gradual expansion to new meanings also supported an explanation of the multifunctionality of the markers in terms of polysemy and a discourse model where the different functions can be derived from the etymological meaning shared by déjà and gia ('already').

The cross-linguistic study of pragmatic markers can also be broadened to involve specific aspects of their use where they may be expected to differ. Pragmatic markers across languages can, for example, be compared with regard to their positions in the clause peripheries for expressing textual, subjective and intersubjective meaning (Beeching and Detges, 2014: 11). Beeching and Detges formulated the hypothesis that the left and right peripheries of the clause would be exploited for communicative purposes in a cross-linguistically consistent way. Then and its Swedish cognate $d \stackrel{a}{a}$ are, for instance, similar in that they are found both in the left and right periphery of the clause with specific discourse functions. However, the functions they have in these positions only partially overlap and there are differences in the frequency with which then and då occur in the left and right periphery (Altenberg, 2010; 
Aijmer, 2018). The position of discourse markers in the left and right peripheries also reflects a diachronic scenario where a lexical element first has meaning on the referential level, and then develops textual (or subjective) meanings in the left periphery and, finally, intersubjective meanings in the right periphery (Traugott, 2014).

\subsubsection{Contrastive Analysis of Sociolinguistic Aspects of Pragmatic Markers}

The contrastive analysis of pragmatic phenomena can also involve sociolinguistic aspects and the way in which sociolinguistic factors can explain cross-linguistic differences. Stenström (2006) contrasted the English discourse marker okay with its closest Spanish correspondence vale in light of their frequency and usage in the Spanish teenage corpus Corpus Oral de Lenguaje Adolescente de Madrid (COLAm) and the Bergen Corpus of London Teenage Language (the COLT Corpus), respectively. The analysis of the age and gender of the speakers further highlighted the importance of cultural and social practices when explaining the differences in the frequency and use of the markers. The results showed, for example, that Spanish girls used vale most frequently, whereas English boys used okay the most.

\subsection{Speech Acts in a Contrastive Perspective}

Speech acts are an important area of research in pragmatics. However, the complexities involved with studying the realisations of speech acts on the basis of corpora are well known. One reason is that within a single language a speech act can be realised in various different ways which are conventionalised to different extents. The methodological problems relating to the question of 'a tertium comparationis' become even more serious when we examine speech acts across languages.

As a result, the methods most frequently employed in empirical research on speech acts or pragmatic markers, both contrastively and in a single language, have been discourse-completion tasks (DCTs) and role-plays (Beeching, 2015; Blum-Kulka et al., 1989). These are well-established and popular methodologies for collecting comparable speech act data because they enable like-for-like comparison. Discourse-completion tasks make it possible to collect large amounts of data in a short time. "Hundreds, if not thousands of studies" have been conducted by employing this method to investigate speech acts, in particular requests and apologies across languages or varieties of the same language (Schneider, 2018: 221; cf. Blum-Kulka et al., 1989; Trosborg, 1995). In these studies, the focus has been on the importance of analysing the sociocultural practices which underlie the cross-linguistic differences, and how 
sociolinguistic variables such as social power, the social distance between speakers and the degree of imposition are reflected in the linguistic realisation of speech acts. Requests and apologies have, for instance, been studied in a large number of projects with the aim of investigating how these sociolinguistic variables have an impact on the interpretation of the speech act and how these variables can be perceived differently depending on the culture and language. The same methodology has also been used in studies which examine how native and non-native speakers of the same language perform speech acts (see e.g. DeCapua and Dunham (2007) on the giving of advice by native and non-native speakers of American English).

On the other hand, there are obvious advantages of studying speech acts in authentic discourse. We can, for example, obtain a broader contextual picture of the stretch of discourse accommodating a speech act, such as a request, which can extend over several speaker turns (O'Keeffe, 2018: 596). ${ }^{6}$ As has been shown in a number of studies, it is also possible to use a function-toform approach based on the definition of the function of the speech act as the starting-point for the analysis.

Marsily (2018) investigated request realisations in (Belgian) French and Spanish with the aim of exploring the notion of equivalence in a pragmatic context. The study was based on natural corpus data, including conversations between family members, friends and classroom interactions (p. 123). In order to examine the notion of pragmatic equivalence, she developed a taxonomy of requests which was used to analyse the requests in the Spanish and French data. It was shown that that some formulations were similar in the two languages but that their pragmatic interpretation or frequency differed.

Fetzer (2011: 74) argued that departing from pragmatic function to study speech act realisations involves systematising the contextual constraints on the speech act and mapping the constraints on to the linguistic form in the languages being compared. The necessary and sufficient contextual constraints on a speech act are, for example, specified in the theory of speech acts (Searle, 1969), but other accounts which consider the connection between the contribution provided by the speech act and preceding talk may also be used to define the contextual configuration which serves as the 'tertium comparationis' for the contrastive analysis. Fetzer (2011) illustrated this approach with a contrastive analysis of challenges in corpora of English and German political interviews. English and German offered a number of different linguistic forms

6 A new development in contrastive corpus pragmatics which will facilitate the comparison of speech acts across languages is pragmatic corpus annotation having speech acts as the target (Rühlemann and Aijmer, 2015: 11f.; Archer and Culpeper, 2018). 
which met the necessary contextual conditions for challenges. However, the relationship between function and form was not straightforward since the function could also be manifested prosodically, and the function of challenging needed to take into account their role in the sequential organisation of the discourse. The results obtained by comparing the linguistic realisations of challenges across both English and German showed that German challenges were less varied than British challenges, and the forms were used with different frequency in German and English.

\subsection{Contrastive Analysis of the Pragmatic Aspects of Genres}

Over the last few decades there has been increasing interest in how the frequency and use of lexical and grammatical structures across languages are determined by the genre or register in which they are found. ${ }^{7}$ Genres often show distinct patterns of frequency, distribution of linguistic features and usage in relation to other genres or ordinary language use (Aijmer and Lewis, 2017: 2). A genre-based perspective implies an explanation of the formal and functional properties of pragmatic patterns in light of the needs that these patterns fulfil in the speech situation which is typical of the communicative genre. Genre is now often included in contrastive studies of discourse relations, pragmatic markers, speech acts and information structure (e.g. the use of dislocation).

\subsubsection{Discourse Relations in a Contrastive Genre Perspective}

An excellent illustration of how adding a genre perspective can enrich the crosslinguistic analysis of discourse-pragmatic phenomena is provided by Lewis (2017). Lewis' aim was to test the hypothesis that there are differences between English and French in the area of discourse marking and that these differences could also be due to the genre. This area of research was delimited to additive discourse-marking linguistic devices such as English also, indeed, too and their French correspondences in public speeches by English and French politicians. The corpus analysis showed that there were differences in the frequency of additive markers and that the 'over-representation' of additive markers in French could be explained both with reference to the rhetorical patterns of the genre and language-specific preferences for a certain pattern. French political speeches were, for example, shown to have more frequent and varied additive discourse marking than English speeches. According to Lewis, these differences can explain why French speeches convey a literary impression as well

7 There is no agreement about terminology in this area but scholars use terms such as genre, register, text type and activity type (see Aijmer and Lewis, 2017: 2). 
as a degree of formality that is not present in English political speeches, due to the greater distance that exists between literary and conversational French than in English (Lewis, 2017: 158).

Fetzer and Speyer (2019) further extend our understanding of the scope of contrastive corpus pragmatics to genres by comparing discourse relations and their linguistic realisations in four different data sets: editorials from British and German newspapers and personal narratives written by British and German students. The results of this 'doubly contrastive' analysis of discourse relations across genres and languages showed, for example, that the overt realisation of discourse relations is genre-specific in both English and German.

\subsubsection{Information Structure in a Contrastive Perspective}

Callies and Levin (2019) investigated the frequency and distribution of (right) dislocation in comparable English, German and Swedish live football commentaries. Right dislocation can be illustrated by the following example (from the football commentary): "Well they had a rocky few minutes, Germany" (abbreviated from the original) (Callies and Levin 2019: 254). Callies and Levin found that the use of right dislocation was about ten times more frequent in live TV football commentaries than in conversation (in English), demonstrating that the pattern needed to be analysed in terms of the contextual parameters of the genre. Callies and Levin's analysis showed that the communicative functions of right dislocation in their data (e.g. to resolve ambiguities resulting from a mismatch between the commentary and the on-screen image or the addition of information) could be explained by the unplanned nature of the football commentary resulting from the need for the commentators to synchronise what is said with the moving image on the TV screen. However, the results did not show any differences between the languages being compared.

\subsubsection{Politeness in a Contrastive Genre Perspective}

Politeness has been studied contrastively in specialised (written) genres such as book review articles or research articles in different languages. Diani (2015) has contributed to this research by studying how criticism is mitigated differently in Italian and British book review articles. Her hypothesis was that there are explicit cultural variations in the linguistic devices and structures used to express positive or negative politeness in academic book reviews. In order to examine how criticism was expressed in Italian and English, two comparable corpora of book review articles were compiled from historical journals published in English and Italian, respectively. Instances of criticism were identified 'by manual sorting and sifting' and a list of mitigation strategies compiled, recognised as such by the presence of various negative lexical features. The results showed that there was a high percentage of criticism accompanied by praise 
and that hedging strategies (such as modal auxiliaries or the modal verb seem) were also frequent. Moreover, the Italian book review articles contained a lower proportion of hedges than the English articles, and suggestions as a form of indirect criticism were more frequent than in English. The results reflect both "the values inherent in a discipline's epistemology" (Diani, 2015: 185) and national or cultural tendencies.

\subsection{Summing $U p$}

In this section, the focus has been on what contrastive corpora and corpuslinguistic methods can offer the scholar interested in pragmatics and what challenges are faced by contrastive pragmatics. Contrastive pragmatics is closely associated with the use of parallel and comparable corpora for studying the similarities and differences between languages. Parallel corpora have now been extended to more than two languages making them more relevant for typological research, and they can be used to investigate the presence of (discourse) universals across languages. Scholars have also begun to combine contrastive analysis (translations) with the diachronic analysis of pragmatic phenomena in historical corpora, and pragmatic phenomena are studied contrastively with the focus being on sociolinguistic aspects.

Methodologically, there have also been several advances. Corpora are closely associated with a form-to-function approach and lend themselves to the study of specific lexical items, such as pragmatic markers, in different languages. There are also a number of possible approaches that can be adopted for the function-to-form analysis of speech acts such as challenges or requests.

\section{$4 \quad$ A Case Study of English absolutely and Swedish absolut}

\subsection{Introduction}

The aim here is to provide a case study of the cognates absolutely in English and absolut in Swedish. The empirical study will show how a contrastive corpusbased methodology can be useful for detecting similarities and differences between near-synonymous elements in two different languages. The trigger for the comparative research comes from an article contrasting absolutely with its Spanish correspondence absolutamente (Carretero, 2010). Carretero compared the meanings of absolutely and absolutamente in spoken and written texts in the British National Corpus and Corpus de referencia del español for Spanish. Carretero's starting point was the observation that the adverbs were multifunctional and were not used in the same way in the English and Spanish corpora. The hypothesis proposed by Carretero to explain the differences implied that absolutely and absolutamente, in some contexts, operate at a clausal level and 
express more subjectivity (a strong pragmatic attitude to the proposition). When used like this, absolutely/absolutamente would be closely related to certainly and definitely. The assumption was also that the meaning of strong subjectivity would be different for absolutely and absolutamente. By adding examples of cognates of absolutely from other languages, we can contribute to the debate about the relationship between the intensifying word-modifying intensifier and its use at both the clausal level and in discourse.

My aim here is, then, to compare English absolutely and Swedish absolut by focusing on their distributional similarities and differences, their capacity to express certainty (rather than degree of intensification) and the uses that they have as an independent discourse marker with a response function. Absolutely and absolut have their origins in the Latin adverb absolete and have developed the adverbial meaning 'completely' (cf. oed Online 'absolutely'). It can therefore be hypothesised that they should develop similar functions. The multifunctionality of absolutely and absolut can be described in detail by taking into account how their meanings and functions are mirrored when translated into the other language. A contrastive analysis can also lead to deeper theoretical questions about the grammaticalisation or pragmaticalisation that absolutely and absolut have undergone.

\subsection{Absolutely and absolut in a Contrastive Perspective}

The fictional part of the English-Swedish Parallel Corpus (ESPC) has been used for this study (1.5 million words) (see Altenberg et al., 2001 for more information about the corpus). Since the ESPC is a bidirectional corpus it is possible to include both translations and back-translations of absolutely/absolut (going from the translations to the original texts).

Quirk et al. (1985) describe absolutely as a degree adverb or (maximising) amplifier which performs the function of scaling the properties of an adjective upwards from an assumed norm. However, absolutely can perform the function of modifying many different kinds of words besides adjectives, and can also perform functions where it does not modify words. Carretero (2010) classified the occurrences of absolutely and Spanish absolutamente into modifiers of words and clausal constituents (e.g. cases where absolutely or absolutamente are oriented to the verb phrase). The findings from the comparison provided evidence that differences existed between English and Spanish adverbs. This leads one to believe that there might also be differences between absolutely and absolut.

In order to investigate this aspect, instances of absolutely and absolut (in both translation directions) were retrieved from the English-Swedish Parallel Corpus and classified according to their syntactic function. The occurrences of Swedish absolut where the lexical form had an adjectival function were excluded. 
Table 1 shows absolutely and absolut (originals and translations) followed by adjectives, determiners, pronouns, modal auxiliaries, nouns, verbs and negators. Absolut can also stand alone (independent use) where it takes on the function of a discourse marker.

TABLE 1 The frequencies of absolutely and absolut with different collocations and in independent use (as a discourse marker) in the English-Swedish Parallel Corpus (ESPC)

\begin{tabular}{lccr}
\hline Collocational patterns & Absolutely & Absolut & Total \\
\hline Adjective & 28 & 7 & 35 \\
$\begin{array}{l}\text { Determiner (no) } \\
\text { (Swe. 'ingen', 'inget') }\end{array}$ & 1 & 2 & 3 \\
Pronoun (nothing, everything, everyone) & 8 & 5 & 13 \\
(Swe. 'ingenting') & & & \\
Modal auxiliary & 1 & 6 & 7 \\
Noun (phrase) & 1 & - & 1 \\
Verb & 4 & 3 & 7 \\
Negator (not/'inte') & 1 & 3 & 16 \\
Independent use & 1 & 41 & 86 \\
Total & 45 & & \\
\hline
\end{tabular}

The patterns are illustrated below:

Adjective:

(1) It looks absolutely frightful! (RD1)

Det ser fullkomligt gräsligt ut! (RDıT)

(Lit. 'It looks completely frightful')

Determiner:

(2) Sorry, absolutely no reason why you should. (JB1)

Förlåt, det finns ju absolut inget skäl till att ni skulle märka det. (JBiT)

(Lit. 'Sorry, there is of course no reason why you should notice it.')

8 The reference is to the text (name of author). See http://www.tekstlab.uio.no/cgi-bin/omc/ PerlTCE.cgi. ' $T$ ' at the end of the reference tag means that the sentence is a translation. 
Pronoun:

(3) He had absolutely nothing to say. (HMiT)

Han hade absolut ingenting att säga. (HMi)

Auxiliary:

(4) When he absolutely had to shake hands with some fellow who didn't get his clear signals, he would shoot off to the washroom as soon as he could and wash his hands. (RDA1)

När han var absolut tvungen att skaka hand med någon som inte hade uppfattat hans klara signaler, rusade han alltid iväg till toaletten och tvättade händerna så fort han kunde. (RDAıT)

(Lit. 'When he was absolutely forced to ...')

Noun phrase:

(5) It seemed to me that whatever else was true, it was absolutely the case that Ty deserved to realize some of his wishes. (JSM1)

Min uppfattning var att hur det än var för övrigt, så var det inget tvivel om att Ty förtjänade att få några av sina önskningar uppfyllda. (JSMiT)

(Lit. 'was there no doubt that ...')

Verb:

(6) It's tidy and self-contained and all of it suits me absolutely. (SG1)

Lägenheten är lättstädad, innehåller allt jag behöver och passar mig perfekt. (SG1T)

(Lit. 'suits me perfectly')

Negator:

(7) Han stod där med sitt sherryglas, svettades lite vid tinningarna, var absolut inte i sitt rätta element, kämpade så förtvivlat för att klara av det hela. (JBiT)

Standing there with his schooner of sherry, perspiring a little at the temples, clearly not in his element, and trying painfully hard to overcome it. (JB1) 
Independent use:

(8) "Och alltsammans förgäves?"

"Absolut." (BRiT)

"And all in vain?"

"Sure." (BR1)

Absolutely was used most frequently to modify an adjective in the ESPC (Table 1) which agrees with Carretero's findings that absolutely modified an adjective in more than half of the examples in the British National Corpus $(55.6 \circ \%$ of all occurrences). Absolut was particularly common with modal auxiliaries and negators. It was also found in independent use where it has the discourse function of responding to the preceding discourse.

In the following sections I will analyse absolutely and absolut in different collocational contexts and will concentrate on what the translations tell us about their interpretations. The focus of the analysis will be on cases where absolutely and absolut do not correspond with each other and where the translation or the source functions as a cue to the meaning of absolutely/absolut. A list of the translational correspondences of absolutely and absolut is provided in the Appendix.

\subsubsection{Absolutely/absolut Modifying an Adjective}

In a contrastive perspective there may also be differences associated with the frequency with which absolutely and absolut occur in different contexts. Translating into the other language can provide a measure of how absolutely/ absolut is used and how the languages differ from each other. The Swedish correspondences of absolutely suggest that its synonyms are other degree modifiers such as completely (Swe. 'fullkomligt', 'fullständigt'), quite (Swe. 'alldeles'), unquestionably (Swe. 'ovedersägligen'), exactly (Swe. 'precis') or entirely ('helt'):

(9) It looks absolutely frightful! (RD1)

Det ser fullkomligt gräsligt ut! (RDıT)

(10) This ivy which grew on the west side of his house had gone absolutely apeshit, almost covering it. (SKı)

Murgrönan som växte på den västra sidan av huset hade blivit alldeles galen och täckte nästan hela väggen. (SKıT) (Lit. '... and covered almost the whole wall') 
Another clue to how absolutely/absolut is used is provided by the semantic type of the adjective and the language-specific constraints on the meaning of the adjective co-occurring with the intensifier.

Absolutely co-occurs with several semantic types of adjectives. The English adjectives express mirativity (astounding), necessity (necessary), evaluation (crazy, genuine, furious, terrible, frightful, awful, apeshit), certainty (certain, sure) and truth (true). The adjectives which expressed evaluation usually had negative connotations.

The differences between absolutely and Swedish absolut are striking. Swedish absolut was used infrequently with adjectives, being found only with a few semantic types of adjective (certainty, necessity), and it was never found with speaker-oriented or evaluative adjectives.

\subsubsection{Absolutely/absolut Collocating with a Pronoun}

A distinction needs to be made between absolutely and absolut when modifying a pronoun ('nothing', 'everyone', 'everything'). Absolut is more easily associated with the speaker's perspective than absolutely and can have a more general meaning to emphasise the assertion. The speaker is certain that nothing unsettling leaps to mind:

(11) "I lördags, menar ni?"

Han skakade på huvudet.

"Inget jag kommer ihåg nu.

Absolut inget osedvanligt." (MWiT)

"On Saturday, you mean?"

He shook his head.

"Nothing that leaps to mind.

Certainly nothing unsettling." (MW1)

It can be concluded (from the English correspondence 'certainly') that absolut has scope over the whole utterance and is anchored in the speaker's perspective.

Absolutely, on the other hand, focuses on the pronoun and not on what is asserted to be true:

(12) He had absolutely nothing to say. (HMiT)

Han hade absolut ingenting att säga. (HMı) 
When absolutely was used before a pronoun it was a maximiser and had only weak subjective meaning. ${ }^{9}$

4.2.3 Absolutely/absolut Collocating with a Modal Auxiliary

Absolut was used more frequently than absolutely before an auxiliary. In (13) the English source text gives an indication that absolut corresponds to certainly when it collocates with an auxiliary:

(13) Om det är möjligt att få en presentation till stånd, kommer den absolut att äga rum. (RDArT)

If the presentation can be managed, it will certainly be done. (RDA1)

In (14) skulle (would) absolut in the Swedish translation corresponds to 'would certainly' in the English source text:

(14) Det skulle vi absolut ha hört (MWiT)

We'd certainly have heard that (MW1)

Absolutely/absolut maximises a property on a degree scale while certainly attributes the maximum degree of certainty to the proposition. However, they are closely related as shown by the fact that they can be translational correspondences when the auxiliary which has been modified by absolut has speaker-oriented meaning (cf. will, would).

Direct translation between absolutely and absolut is not possible, and this is indicated by the fact that absolutely was not found in contexts where an auxiliary such as will or would is modified.

In (15) absolut måste ('must') conveys the speaker's certainty that her forebears had been supporters of the Stuarts:

(15) Hon hade en romantisk föreställning om att hennes förfäder, som varit höglandsskottar, absolut måste ha varit anhängare av ätten Stuart. (RDAıT)

It was her romantic notion that her forebears, as Highland Scots, must necessarily have been supporters of the Stuarts. (RDA1)

9 Absolutely/absolut also co-occur with determiners (= no). Both absolutely and absolut modified the determiner in these cases. 
Must necessarily in the English source text suggests that the speaker expresses a high degree of commitment to the proposition based on her assessment of the situation. If the auxiliary or semi-modal modified by absolutely/ absolut has deontic meaning, then the subjective perspective is lost and both absolut and absolutely could be used as strongly reinforcing modifiers of the obligation:

(16) När han var absolut tvungen att skaka hand med någon som inte hade uppfattat hans klara signaler, rusade han alltid iväg till toaletten och tvättade händerna så fort han kunde. (RDArT)

(Lit. 'was absolutely obliged')

When he absolutely had to shake hands with some fellow who didn't get his clear signals, he would shoot off to the washroom as soon as he could and wash his hands. (RDA1)

4.2.4 Absolutely/absolut Collocating with Verbs

Absolutely can also be a modifier of lexical verbs, thus performing the function of emphasising the verb. It has several different Swedish correspondences. It can be translated by its cognate:

(17) He refused absolutely to own jumpers on the grounds that he might buy something that would kill me. (DF1)

Han vägrade absolut att äga hinderhästar därför att han då kanske skulle ha köpt något som kunde döda mig. (DFıT)

The translation has 'perfekt' (perfectly):

(18) It's tidy and self-contained and all of it suits me absolutely. (SG1)

Lägenheten är lättstädad, innehåller allt jag behöver och passar mig perfekt. (SG1T)

In (19) the Swedish original contains 'obetingat' (necessarily):

(19) He could rely on her absolutely - that applied to all of them. (KOB1T)

Hon skilde sig inte från de övriga därigenom att han obetingat kunde lita på henne. Det gällde dem alla. (KOB1) 
Absolut modifying a verb has a more general meaning when it expresses certainty (definitely):

(20) Alkohol stannar absolut kvar i kroppen (AT1T)

Alcohol was definitely retained. (AT1)

4.2.5 Absolut Collocating with a Negator

When absolut collocates with a negator (inte 'not') it expresses the speaker's certainty that the proposition is not true. In (21) the English source contains the evidential clearly, meaning that something is self-evident and, therefore, certain.

(21) Han stod där med sitt sherryglas, svettades lite vid tinningarna, var absolut inte i sitt rätta element, kämpade så förtvivlat för att klara av det hela. $(\mathrm{JB} 1 \mathrm{~T})$

Standing there with his schooner of sherry, perspiring a little at the temples, clearly not in his element, and trying painfully hard to overcome it. (JB1)

In (22) absolut is placed outside the clause (a clause fragment) and performs the function of emphasising what has been asserted (certainly not to-day or tomorrow). The discourse function can be regarded as concessive because of the following but (one may yearn back to one's own people as one gets older). The English correspondence is an epistemic adverb.

(22) Inte i dag eller i morgon, absolut inte, men om ett år, om fem år, om tjugo, när man blev äldre och kanske började känna sig mer främmande, började längta tillbaka efter "de sina" vad nu de kan betyda. (BRıT)

Not today or tomorrow, certainly not, but in a year's time, in five years, in twenty, as one grew older and began to feel, perhaps, more out of place, to yearn back for "one's own", whatever that might be. (BRi)

In (23) absolut is associated with negative polarity and performs the discourse function of giving a negative response to the preceding question:

(23) Hon sa, De är alla döda, när hon ringde 999.

Tycker du att jag överreagerade?

Nej, sa Wexford långsamt, nej, absolut inte. (RRıT) 
She said, They're all dead when she made her 999 call.

You think I over-reacted, do you?

No, said Wexford slowly, no, not at all. (RR1)

\subsubsection{Absolutely as a Response Marker}

Absolutely/absolut can also occur on its own featuring "a complex interaction with discourse structure and subjectivity" (Beltrama, 2017: 159). All examples of the independent use of absolutely and absolut are found in contexts where the interactional work between the speaker and hearer is important. The lexical meaning has disappeared and absolutely/absolut performs the function of expressing the speaker's positive assessment of what has been said in the preceding discourse. According to Athanasiadou, the speaker perspective "is extreme" when absolutely/absolut is used to provide a response to a question or a statement (Athanasiadou, 2007: 563). In (24), the preceding sentence in the discourse contains a yes-no question:

(24) - Skulle det roa dig att bli påmind om historien så långt som du och jag känner till den? Sa ängeln.

- Ja, absolut. (RDA1T)

- Would it amuse you to be reminded of the story, so far as you and I can know it? said the Angel.

- Indeed, it would. (RDA1)

Absolut expresses agreement with the preceding speaker. It means certainty as shown by its correspondences (indeed, sure, certainly).

Absolutely was found only once as a response marker in the English translation (from a Swedish original alldeles riktigt 'quite so'):

(25) Isn't that one of the basic features of all religions?

That God will help us to overcome our weaknesses?

Absolutely. (HM2T)

Är det inte ett av grundinslagen i alla religioner?

Att Gud ska hjälpa oss att överkomma vår svaghet?

Alldeles riktigt. ( $\left.\mathrm{HM}_{2}\right)$

4.2.7 A Note on absolutely/absolut in Negative Constructions

The high frequency with which absolutely/absolut occurs with negative elements (not, no, nothing, etc.) suggests that the adverbs can be regarded as a 
general resource for strengthening negation (Palacios Martínez, 2016). It can also be observed that the OED Online has a special entry for absolutely in negative constructions: at all, to any extent, whatsoever (oED A.1.b).

The English translational correspondences contain the negative polarity items (not) at all, by no means, not ... by any means. The Swedish correspondences can be illustrated by (inte) ett spår ('not a bit') and (inte) över huvudtaget ('not in any way'). Absolutely not was also used on its own to give a categorical answer to a preceding request (cf. Section 4.2.5):

(26) Then we'd better split the bill.

No, absolutely not. (JGiT)

Då är det bäst vi delar på notan.

Nej absolut inte, det var jag som bjöd. (JG1)

In negative constructions absolutely/absolut can be compared with certainly, definitely.

\section{$5 \quad$ Summing Up the Case Study}

Absolutely/absolut is an intensifier with a meaning that maximises the degree of a property. At the clausal level it can express certainty and have a strengthening effect on the illocutionary force conveyed by the assertion. However, the boundary between the degree of intensification (maximising the degree of a property on a scale) and certainty (the degree of commitment to the truth of the proposition) may become blurred.

The theoretical question is how we should describe the relationship between the meaning of absolutely (and absolut) as a modifier of words and its functions at the clausal level for conveying the speaker's commitment or other speaker attitudes. Absolutely is, for example, always interpreted as a maximising intensifier before adjectives. In other contexts, it is more likely that the speaker has used the adverb to mean 'certainly' or 'definitely' to present the situation from a subjective or speaker perspective. The polysemy of absolutely/absolut is in line with the assumption that it does not have a fixed meaning but a core meaning from which other meanings or functions can be derived in the communication situation. The epistemic or emphasising meaning of absolutely (or absolut) would, for example, seem to derive from the meaning 'completely' by 
implicature ${ }^{10}$ when the adverb collocates with modal auxiliaries, which imply that the speaker makes an assessment of the truth of the sentence, or with a negator. Absolutely/absolut can also be used on its own with the heareroriented function of agreeing with the information provided by the preceding speaker at a particular point in the evolving discourse.

On the basis of synchronic contrastive data it has been shown that we can identify situations where absolutely and absolut are used in the same way, but there are also situations where the translations show that they do not correspond with one another. For example, absolut was not found as an intensifier before evaluative adjectives and it was more frequently used with epistemic or emphasising meaning (increasing the speaker's commitment to the truth of the utterance) than absolutely.

The similarities and differences between absolutely and absolut can also be problematised in a diachronic perspective. According to the oED Online (III.8), absolutely originally had the meaning 'in a manner detached from other things; without reference to, consideration of, or dependence upon anything external, circumstantial, or accidental'. From the 15th century, absolutely is attested with the meaning of completely, perfectly: OED Online (I.1.a. To the fullest extent; in the highest degree; entirely, wholly, utterly. In later use frequently as a simple intensifier). It can also have the meaning 'unreservedly, wholeheartedly, unconditionally' (OED Online II.5). At the beginning of the 18th century absolutely is also found with epistemic meaning ('actually', 'in truth', 'modifying the statement as a whole'; OED Online 6.). The oEd Online also gives examples of a colloquial use of absolutely with the meaning 'yes', 'certainly' (B.1.) dating back to the 19th century. We can make a comparison with the semantic developments undergone by the Swedish absolut. According to the ААО (the Swedish Academy Dictionary), the adverbial meaning of absolut (to the fullest extent, altogether) is attested from the beginning of the 18th century. The adverbial absolut is also found with the meaning 'unreservedly', 'unconditionally'. However the ААОв does not mention the epistemic meaning, and the colloquial use of absolut as a response marker is not recorded.

10 Cf. also Traugott and Dasher's (2002) 'Invited Inferencing Theory of Semantic Change' where pragmatic theories of pragmatic implicature play an important role in explaining semantic change. 


\section{Appendix}

TABLE 2 The Swedish correspondences of absolutely in the English-Swedish Parallel Corpus

\begin{tabular}{|c|c|c|c|}
\hline & $\begin{array}{l}\text { Swedish } \\
\text { sources }\end{array}$ & $\begin{array}{l}\text { Swedish } \\
\text { translations }\end{array}$ & Total \\
\hline absolut & 4 & 9 & 13 \\
\hline alldeles ('quite') & 1 & 6 & 7 \\
\hline rent, rena ('downright') & - & 2 & 2 \\
\hline ovedersägligen ('unquestionably') & 1 & - & 1 \\
\hline fullständigt ('completely') & 1 & - & 1 \\
\hline (det är) inget tvivel om ('no doubt about') & 1 & - & 1 \\
\hline fullkomligt ('completely') & 1 & - & 1 \\
\hline perfekt ('perfectly') & 1 & - & 1 \\
\hline (inte) ett spår ('not at all') & - & 1 & 1 \\
\hline enormt ('enormously’) & 1 & - & 1 \\
\hline alldeles riktigt ('quite right') & - & 1 & 1 \\
\hline mycket riktigt ('rightly') & - & 1 & 1 \\
\hline (det är) min förvissning ('my certainty') & - & 1 & 1 \\
\hline obetingat ('necessarily') & - & 1 & 1 \\
\hline med bestämdhet ('firmly') & - & 1 & 1 \\
\hline helt ('entirely') & - & 2 & 2 \\
\hline oerhört ('incredibly') & - & 1 & 1 \\
\hline överhuvudtaget ('at all') & - & 1 & 1 \\
\hline precis ('exactly') & - & 1 & 1 \\
\hline$ø$ (untranslated) & 1 & 3 & 4 \\
\hline other* & 1 & 1 & 2 \\
\hline Total & 13 & 32 & 45 \\
\hline
\end{tabular}

* The examples are:

Our Lord couldn't do absolutely everything in one week. (ARP1)

Vår herre kunde ju inte hinna med allting på en vecka. (ARP1T)

(Lit. 'couldn't of course have the time to do everything')

That's what I gathered anyway, but I am not absolutely sure. (RJiT)

Det är vad jag tror och har listat ut själv så ingenting är säkert, men ganska mystiskt eftersom jag ingenting får veta bestämt. (RJ1)

(Lit.... 'so nothing is certain but rather strange since I am told nothing definitely') 
TABLE 3 The English correspondences of absolut in the English-Swedish Parallel Corpus

\begin{tabular}{lccr}
\hline & English sources & English translations & Total \\
\hline absolutely & 10 & 4 & 14 \\
certainly & 1 & 5 & 6 \\
by no/any means & - & 2 & 2 \\
none at all & 1 & - & 1 \\
impossible & 1 & - & 1 \\
completely & 1 & - & 1 \\
simply & 1 & - & 1 \\
totally & 1 & - & 1 \\
not at all & - & 1 & 1 \\
definitely & - & 1 & 1 \\
sure & - & 1 & 1 \\
necessarily & - & 1 & 1 \\
truly & - & 1 & 1 \\
clearly & - & 1 & 1 \\
$\emptyset$ (untranslated) & 3 & 3 & 6 \\
other & 1 & 21 & 2 \\
Total & 20 & & \\
& & &
\end{tabular}

\section{References}

Aijmer, Karin (ed.). 2011. Contrastive pragmatics. Amsterdam/Philadelphia: John Benjamins.

Aijmer, Karin. 2015. Well in an English-Swedish and English-French contrastive perspective. In: Kate Beeching, and Helen Woodfield (eds.), Researching sociopragmatic variability. Perspectives from variational, interlanguage and contrastive pragmatics. Basingstoke: Palgrave Macmillan, 201-229.

Aijmer, Karin. 2018. Challenges in the contrastive study of discourse markers. The case of then. In: Óscar Louredá, Inés Recio Fernández, Laura Nadal, and Adriana Cruz (eds.), Empirical studies of the construction of discourse. Amsterdam/Philadelphia: John Benjamins, 17-42.

Aijmer, Karin, and Diana Lewis. 2017. Introduction. In: Karin Aijmer, and Diana Lewis (eds.), Contrastive analysis of discourse-pragmatic aspects of linguistic genres. Cham, Switzerland: Springer, $1-9$. 
Aijmer, Karin, and Anne-Marie Simon-Vandenbergen. 2003. The discourse particle well and its equivalents in Swedish and Dutch. Linguistics 41(6): 1123-1161.

Aijmer, Karin, and Anne-Marie Simon-Vandenbergen. 20o6. Pragmatic markers in contrast. Amsterdam: Elsevier.

Aijmer, Karin, Bengt Altenberg, and Mats Johansson(eds.). 1996. Languages in contrast: Papers from a symposium on text-based cross-linguistic studies, Lund 4-5 March 1994. Lund: Lund University Press.

Altenberg, Bengt. 2010. Conclusive English then and Swedish då. A corpus-based contrastive study. Languages in Contrast 102-103.

Altenberg, Bengt, and Karin Aijmer. 20oo. The English-Swedish Parallel Corpus: A resource for contrastive research and translation studies. In: Christian Mair, and Marianne Hundt (eds.), Corpus linguistics and linguistic theory. Papers from the 2oth International Conference on English Language Research on Computerized Corpora (ICAME 20) Freiburg im Breisgau 1999. Amsterdam \& Philadelphia: Rodopi, 15-33.

Altenberg, Bengt, Karin Aijmer, and Mikael Svensson. 2001. The English-Swedish Parallel Corpus (ESPC): Manual. Department of English, Lund University. Available at: http://www.sol.lu.se/engelska/corpus/corpus/espc.html.

Archer, Dawn, and Jonathan Culpeper. 2018. Corpus annotation. In: Andreas H. Jucker, Klaus P. Schneider, and Wolfram Bublitz (eds.), Methods in pragmatics. Berlin/ Boston: De Gruyter Mouton, 495-525.

Athanasiadou, Angeliki. 2007. On the subjectivity of intensifiers. Language Sciences (29): 554-565.

Baker, Mona. 1993. Corpus linguistics and translation studies: Implications and applications. In: Mona Baker, Gill Francis, and Elena Tognini-Bonelli (eds.), Text and technology. In honour of John Sinclair. Amsterdam/Philadelphia: John Benjamins, 235-25o.

Barron, Anne, and Klaus P. Schneider. 2009. Variational pragmatics. Studying the impact of social factors on language use in interaction. Intercultural pragmatics 6(4): 425-442.

Beeching, Kate. 2015. Variability in native and non-native use of pragmatic markers: The example of well in role-play data. In: Kate Beeching, and Helen Woodfield (eds.), Researching sociopragmatic variability. Perspectives from variational, interlanguage and contrastive pragmatics. Basingstoke: Palgrave Macmillan, 174-197.

Beeching, Kate, and Ulrich Detges (eds.). 2014. Discourse functions at the left and right periphery: Crosslinguistic investigations of language use and language change. Leiden: Brill.

Beeching, Kate, and Helen Woodfield. 2015. Introduction. In: Kate Beeching, and Helen Woodfield (eds.), Researching sociopragmatic variability. Perspectives from 
variational, interlanguage and contrastive pragmatics. Basingstoke: Palgrave Macmillan, 1-16.

Beltrama, Andrea. 2017. Totally tall sounds totally younger: Intensification at the sociosemantics interface. Journal of Sociolinguistics 21(2): 154-182.

Blakemore, Diane. 2002. Relevance and linguistic meaning: The semantics and pragmatics of discourse markers. Cambridge: Cambridge University Press.

Blum-Kulka, Shoshana, Juliane House, and Gabriele Kasper. 1989. Cross-cultural pragmatics: Requests and apologies. Norwood, NJ: Ablex.

Buysse, Lieven. 2017. English so and Dutch dus in a parallel corpus: An investigation into their mutual translatability. In: Karin Aijmer, and Diana Lewis (eds.), Contrastive analysis of discourse-pragmatic aspects of linguistic genres. Cham, Switzerland: Springer, 33-61.

Callies, Marcus, and Magnus Levin. 2019. A comparative multimodal corpus study of dislocation structures in live football commentary. In: Marcus Callies, and Magnus Levin (eds.), Corpus approaches to the language of sports. London: Bloomsbury Academic, $253^{-269}$.

Carretero, Marta. 2010. 'You're absolutely right!' A corpus-based contrastive analysis of 'absolutely' in British English and absolutamente in Peninsular Spanish with special emphasis on the relationship between degree and certainty. Languages in Contrast 10(2): 194-222.

Coulmas, Florian. 1981. 'Poison to your soul'. Thanks and apologies contrastively viewed. In: Florian Coulmas (ed.), Conversational routine. Explorations in standardized communication situations and prepatterned speech. The Hague: Mouton Publishers, 69-91.

Davidse, Kristin, and Liesbert Heyvaert (eds.). 2002/2003. Functional linguistics and contrastive description. Special issue of Languages in Contrast 4(1): 1-199.

DeCapua, Andrea, and Joan Findlay Dunham. 2007. Strategies in the discourse of advice. Journal of Pragmatics 20(6): 519-53.

Defour, Tine, Ulricht D'Hondt, Anne-Marie Simon-Vandenbergen, and Dominique Willems. 2010. Degrees of pragmaticalization: The divergent histories of 'actually' and 'actuellement'. Languages in Contrast 10(2): 166-193.

Diani, Giuliana. 2015. Politeness. In: Karin Aijmer, and Christoph Rühlemann (eds.), Corpus pragmatics. A handbook. Cambridge: Cambridge University Press, 169-191.

Dyvik, Helge. 1998. A translational basis for semantics. In: Stig Johansson, and Signe Oksefjell (eds.), Corpora and cross-linguistic research: Theory, method, and case studies. Amsterdam \& Atlanta, GA: Rodopi, 51-86.

Enghels, Renata. 2018. Extending the notion of near-synonymy: Studies in morphological, syntactic and pragmatic equivalence. Languages in Contrast 18(1): $1-5$. 
Ferguson, Charles A. 1981. The structure and use of politeness formulas. In: Florian Coulmas (ed.), Conversational routine. Explorations in standardized communication situations and prepatterned speech. The Hague: Mouton Publishers, 21-35.

Fetzer, Anita. 2011. Challenges in contrast: A function-to-form approach. In: Karin Aijmer (ed.), Contrastive pragmatics. Amsterdam/Philadelphia: John Benjamins, $73-96$.

Fetzer, Anita, and Augustin Speyer. 2019. Discourse relations across genres and contexts: A contrastive analysis of English and German discourse. Languages in Contrast 19(2): 205-231.

Fleischman, Suzanne, and Marina Yaguello. 2003. Discourse markers across languages. In: Carol Lynn Moder, and Aida Martinovic-Zic (eds.), Discourse across languages and cultures. Amsterdam/Philadelphia: John Benjamins, 129-147.

Gast, Volker. 2015. On the use of translation corpora in contrastive linguistics. A case study of impersonalization in English and German. Languages in Contrast 15(1): 4-33.

Gellerstam, Martin. 1996. Translations as a source for cross-linguistic studies. In: Karin Aijmer, Bengt Altenberg, and Mats Johansson (eds.), Languages in contrast. Papers from a symposium on text-based cross-linguistic studies. Lund 4-5 March 1994. Lund: Lund University Press.

Hansen, Maj-Britt Mosegaard, and Erling Strudsholm. 2008. The semantics of particles: advantages of a contrastive and panchronic approach: a study of the polysemy of French déjà and Italian già. Linguistics 46(3): 471-505.

Hansen-Schirra, Silvia, and Stella Neumann. 2012. Corpus methodology and design. In: Silvia Hansen-Schirra, Stella Neumann, and Erich Steiner (eds.), Cross-linguistic corpora for the study of translations: Insights from the language pair English-German. Berlin/Boston: Mouton de Gruyter, 35-52.

Hasselgård, Hilde. 2006. 'Not now' - On non-correspondences between the cognate adverbs now and nå. In: Karin Aijmer, and Anne-Marie Simon-Vandenbergen (eds.), Pragmatic markers in contrast. Amsterdam: Elsevier, 93-113.

Johansson, Stig. 2007. Seeing through multilingual corpora. On the use of corpora in contrastive studies. Amsterdam/Philadelphia.

Kecskes, Istvan. 2017. Cross-cultural and intercultural pragmatics. The Oxford Handbook of Pragmatics. https://www.oxfordhandbooks.com/view/10.1093/oxfordhb/9780199 69796o.oo1.0oo1/oxfordhb-978019969796o-e-29.

Lauwers, Peter, Gudrun Vanderbauwhede, and Stijn Verleyen. 2010. Introduction: How false friends give true hints about pragmatic markers. Languages in Contrast 10(2): 129-137.

Lewis, Diana. 2017. Coherence relations and information structure in English and French political speeches. In: Karin Aijmer, and Diana Lewis (eds.), Contrastive 
analysis of discourse-pragmatic aspects of linguistic genres. Cham, Switzerland: Springer, 141-161.

Macken, Lieve, Orphée De Clercq, and Hans Paulussen. 2011. Dutch Parallel corpus: A balanced copyright-cleared parallel corpus. Meta 56(2): 374-39o.

Marsily, Aurélie. 2018. Directness vs indirectness: A contrastive analysis of pragmatic equivalence in Spanish and French request formulations. Languages in Contrast 18(1): 122-144.

Martinková, Michaela, and Markéta Janebová. 2017. What English translation equivalents can reveal about the Czech 'modal' particle prý: A cross-register study. In: Karin Aijmer, and Diana Lewis (eds.), Contrastive analysis of discourse-pragmatic aspects of linguistic genres. Cham, Switzerland: Springer, 63-9o.

Norén, Kerstin, and Per Linell. 2007. Meaning potentials and the interaction between lexis and contexts: An empirical substantiation. Pragmatics 17(3): 387-416.

O'Keeffe, Anne. 2018. Corpus-based function-to-form approaches. In Andreas H. Jucker, Klaus P. Schneider, and Wolfram Bublitz (eds.), Methods in pragmatics. Berlin/ Boston: Mouton de Gruyter, 587-618.

Palacios Martínez, Ignacio. 2016. Negative intensification in the spoken language of British adults and teenagers. Nordic Journal of English Studies 15: 45-77.

Quirk, Randolph, Sidney Greenbaum, Geoffrey Leech, and Jan Svartvik. 1985. A comprehensive grammar of the English language. London: Longman.

Romero-Trillo, Jesús. 2008. Pragmatics and corpus linguistics: a mutualistic entente. Berlin/New York: Mouton de Gruyter.

Rühlemann, Christoph, and Karin Aijmer. 2015. Corpus pragmatics: laying the foundations. In: Karin Aijmer, and Christoph Rühlemann (eds.), Corpus pragmatics. A handbook. Cambridge: Cambridge University Press, 1-26.

Schneider, Klaus P. 2018. Methods and ethics of data collection. In: Andreas H. Jucker, Klaus P. Schneider, and Wolfram Bublitz (eds.), Methods in pragmatics. Berlin/ Boston: De Gruyter Mouton, 37-93.

Schneider, Klaus P., and Anne Barron (eds.). 2008. Variational pragmatics. A focus on regional varieties in pluricentric languages. Amsterdam/Philadelphia: John Benjamins.

Searle, John. 1969. Speech acts. Cambridge: Cambridge University Press.

Stenström, Anna-Brita. 20o6. Youngspeak: Spanish vale and English okay. In: Karin Aijmer, and Bengt Altenberg (eds.), Advances in corpus-based contrastive linguistics: Studies in honour of Stig Johansson. Amsterdam: Philadelphia, 127-138.

Traugott, Elizabeth Closs. 2014. On the function of the epistemic adverbs surely and no doubt at the left and the right peripheries of the clause. In: Kate Beeching, and Ulrich Detges (eds.), Discourse functions at the left and right periphery: Crosslinguistic investigations of language use and language change. Leiden: Brill, $72-91$. 
Traugott, Elizabeth Closs, and Richard Dasher. 2002. Regularity in semantic change. Cambridge: Cambridge University Press.

Trosborg, Anna. 1995. Interlanguage pragmatics: requests, complaints, and apologies. Berlin/New York: Mouton de Gruyter.

Vyatkina, Nina, and D. Joseph Cunningham. 2015. Learner corpora and pragmatics. In: Sylviane Granger, Gaëtanelle Gilquin, and Fanny Meunier (eds.), The Cambridge handbook of learner corpus research. Cambridge: Cambridge University Press, 281-305.

Wierzbicka, Anna. 2003. Cross-cultural pragmatics: The semantics of human interaction. Berlin/New York: Mouton de Gruyter. 